\title{
Kütüphaneci Eğitiminde Mentorluk Uygulaması: Doğuş Üniversitesi Kütüphanesi Örneği
}

\section{Mentoring Implementation in Librarian Education: The Dogus University Library Example}

\author{
Sönmez ÇELIK*
}

\begin{abstract}
Öz
Bilgiye erişimde temel ögelerden biri olan kütüphanecilerin eğitimi günümüzde giderek önem kazanmaktadır. Mentorluk uygulaması çalışanların eğitiminde, özellikle düşünme becerilerinin üretime aktarılmasında kuramsal bir çerçeve sağlamaktadır. Bu çerçeve çalışanların farkındalık ve yaratıcı düşünme becerileri üzerinde olumlu yönde etkiler yaratmaktadır. Bilginin hızla elektronik ortama göç ettiği, bilgi kaynaklarının şekil değiştirdiği günümüzde, kütüphanelerin değişim yaratma yetkinliğine katkıda bulunabilecek önemli uygulamalardan biri mentorluktur. Bu nedenle çalışmada, mentorluk uygulaması ile kütüphane personelinin eğitimi ve mentorluk uygulamasının kütüphanelerin hizmet verimliliğine katkılarının neler olabileceği değerlendirilmiştir. Doğuş Üniversitesi Kütüphanesinde geliştirilen çeşitli düzeylerdeki mentorluk programlarının uygulanması sonucunda, yeni personelin eğitiminde ve kütüphanenin hizmet verimliliğinde olumlu yönde geri bildirimler sağladığı gözlenmiştir.
\end{abstract}

Anahtar sözcükler: Mentorluk, Üniversite kütüphaneleri, Kütüphaneci, Personel eğitimi, Kütüphane hizmetleri, Verimlilik, Doğuş Üniversitesi Kütüphanesi

\begin{abstract}
With libraries being one of the key elements in information retrieval, the education of the librarian is gaining importance. The mentoring implementation provides a theoretical framework in the education of the library personnel, especially in the progression of their thinking skills into production. This framework provides a positive effect on the awareness and creative thinking skills of the library personnel. Nowadays, with knowledge being transferred into the electronic environment and with the development of information sources, mentoring proves to be a significant tool which offers the potential to contribute significantly to the evolution and efficiency of the library services. Therefore, the present study aims to investigate the implementation of the mentoring program, the education of the librarian and the possible contribution of mentoring program to the efficiency of the library services. As a result of the implementation of the mentoring programs developed at Dogus University Library at various levels, positive feedback has been obtained from the program in terms of training of the new staff and the efficiency of the library services.
\end{abstract}

* Kütüphane ve Dokümantasyon Daire Bşk.: Doğuş Üniversitesi 
Keywords: Mentoring, University Libraries, Librarian, Personal education, Library services, Productivity, Dogus University Library

\section{Giriş}

Türkiye'deki üniversite kütüphanelerinin büyük çoğunluğunda, işe yeni alınan kütüphaneciler için üniversite ve kütüphanedeki bölümler hakkında genel bir bilgilendirme yapılır. Bu bilgilendirmeden sonra personel çalışacağı birimde göreve başlatııı. Çalıştığı ortamı, koşulları ve meslektaşlarını zaman içinde tanır, kendisine verilen görevi daha önceki örneklere bakarak, belli bir oranda kendisinden daha tecrübelilere sorarak işi öğrenmeye çalışır. Paylaşımcı özelliklere sahip tecrübeli personelin bulunduğu yerlerde görev alan genç kütüphaneciler birçok meslektaşına göre oldukça avantajlıdır. Oysa bu ortamı bulamayan genç kütüphaneciler kimi basit uygulamaları bile çok geç öğrenebilmektedir. Bu durum kütüphanelerde verimliliğin artmasının, genç çalışanların ise hızlı bir şekilde eğitilmesi ve geliştirilmesinin önünde önemli bir engeldir. Günümüzde, genç kütüphanecilerin belli bir program dâhilinde, tecrübeli personel tarafından desteklenerek, izlenerek, yönlendirilerek yetiştirilmesi gereklidir. Bu husustaki eksikliğin farkına varan yurt dışındaki önemli kütüphaneler farklı alanlarda yaygın olarak kullanılan mentorluk uygulamasından yararlanmaktadır. Bu uygulama sayesinde genç kütüphaneciler, kısa sürede, biçimlendirilmiş programlar çerçevesinde ve tecrübeli kütüphanecilerin gözetiminde eğitilmektedir. Böylece hem kütüphane hizmetlerinin daha profesyonel ve belli bir bütünlük içinde verilmesi sağlanmakta hem de kütüphanecilerin gelişmesinde onlara yol göstermektedirler.

Türkiye'deki üniversite kütüphanelerinde personel eğitimi konusunda belli bir düzenin olmayışı yetişmiş personel açısından sıkıntı çekilmesine neden olmaktadır. Türkiye İstatistik Kurumu'nun (TÜIK) 2009 yılı verilerine göre Türkiye'deki üniversite kütüphanelerinde toplam 3.867 personel vardır ve bunların 748'i üniversitelerin Bilgi ve Belge Yönetimi bölümlerinden, 941'i diğer fakülte veya yüksekokullardan, 2.178'i de lise ve lise altı eğitim kurumlarından mezundur. Kütüphanecilerin çalışan personele oranı \%19.34'tür. Ölçme, Seçme ve Yerleştirme Merkezi'nin (ÖSYM) 2008-2009 yılı verilerine göre Türkiye'deki üniversitelerde örgün öğrenim görmekte olan öğrenci sayısı 1.746 .336 kişidir (Çukadar ve diğerleri, 2010, 6). Yani örgün öğretimdeki 2.334 öğrenciye bir kütüphaneci düşmektedir. Öte yandan 2011 yılı verilerine göre Türkiye'deki 148 üniversite kütüphanesi yöneticisinden, 72'si üniversitelerin Bilgi ve Belge Yönetimi bölümlerinden mezun, 76'sı diğer fakülte ve yüksekokul mezunlarından oluşmaktadır (Çukadar ve diğerleri, 2011, 6). Üniversitelerin Bilgi ve Belge Yönetimi bölümlerinden mezun öğrenciler iyi bir derece ile mezun olsalar bile uygulama becerileri yeterli olamaz; çünkü uygulama becerisi iş başında kazanılabilir. Bu nedenle Türkiye'deki yetişmiş kütüphaneci sorunun giderilmesi için kütüphanecilere önemli görevler düşmektedir.

Kütüphanecilerin; Türk Kütüphaneciler Derneği (TKD), Üniversite ve Araştırma Kütüphanecileri Derneği (ÜNAK) ve ANKOS gibi çeşitli sivil toplum kuruluşlarının 
geliştirdiği işbirliği toplantıları çerçevesinde sıklıkla bir araya geldikleri ortamlar adeta bir eğitim, tanışma, danışma, bilgi aktarımı, fikir paylaşımı ve çeşitli alanlarda işbirliği çalışmalarının yapıldığı yerlere dönüşmektedir. Belli bir plan dâhilinde yapılmasa da kütüphanecilerin paylaşım konusundaki tutumları, mesleklerini sahiplenmeleri bu işbirliği toplantılarını, kütüphanecilere amaçlanan faydanın çok üstünde katkılar sağlamaktadır. Bu nedenle çoğu kütüphane yöneticisi, genç kütüphanecilerin mesleki gelişimine katkı sağlamak için, kurum bünyesindeki etkinliklere ilaveten onların bu toplantılara katılmasını teşvik etmektedir.

Türkiye'de kütüphaneciler söz konusu gönüllü işbirliği olanakları ve sivil toplum kuruluşları sayesinde elde ettikleri başarılara, genç meslektaşlarını belli programlar dâhilinde eğitmek suretiyle de katkı sağlamayı dâhil etmelidirler; çünkü hızla değişen ve gelişen bilgi hizmetleri bunu zorunlu kılmaktadır. Sınırlı kaynak ve imkânlara rağmen Türkiye'de üniversite kütüphanelerinin ve dolayısıyla bilgi belge hizmetinin geldiği nokta, daha geniş kaynak ve imkânlara sahip birçok ülkedeki bilgi hizmetlerinden geride değildir. Örneğin, Anadolu Üniversite Kütüphaneleri Konsorsiyumu (ANKOS) aracılığıyla kütüphaneler, uygun maliyetlerle daha çok veri tabanı sağlamanın yanında, çeşitli çalışma grupları, işbirliği platformları, ulusal ve uluslararası düzeyde her yıl bir araya gelmenin fırsatlarını da yakalamaktadırlar. Bu fırsatlar, kütüphanecilerin tanışması, çeşitli işbirlikleri kurması, kaynak paylaşımına gitmesi, fikir alışverişinde bulunulması, akademik çalışmalar yapılması gibi çok çeşitli yönlerde katkılar sunmaktadır. Kütüphanecilerin paylaşım konusundaki tutumları hem kendi kütüphanelerinde hem de diğer kütüphanelerde çalışan meslektaşlarıyla olan ilişkileri, meslektaşlarının ve dolayısıyla kütüphanelerinin gelişmesine, daha iyi hizmet vermesine önemli katkılar sağlamaktadır.

Geleneksel hiyerarşik düzen içinde personelin eğitilmesi geleceğin kütüphanecilerini ve liderlerini yetiştirmek için yeterli değildir (Murphy, 2008, 435). Üniversite kütüphaneleri işe yeni başlayan kütüphanecilerin bir an önce işe adapte olmasını isterler ve bu nedenle onların eğitimi için değişik modellerden yararlanmak isterler (Bosch ve diğerleri, 2010). Yaptıkları işbirliği ve paylaşımlarıyla hizmet kalitesi gelişen, kaynakları her geçen gün daha da zenginleşen üniversite kütüphanelerinde çalışan kütüphanecilerin planlı bir şekilde eğitilmesi ve bu yolla hizmet kalitesinin artırılması sağlanmalıdır. Üniversite kütüphanelerinin, genç kütüphanecilerin eğitiminde son yıllarda yaygınlaşan mentorluk uygulamalarından yararlanması ve hali hazırda belli bir düzeni olmayan personel eğitimini mentorluk uygulamaları çerçevesinde gerçekleştirmeleri faydalı ve gerekli görülmektedir. Bu bakımdan mentorluk, mentorluk uygulaması, mentorluk türleri ve mentorlarda bulunması gereken niteliklerin yanında, kütüphanecilik literatürde yer alan mentorluk uygulamalarına ilişkin örneklerin değerlendirilmesi, Doğuş Üniversitesi Kütüphanesi'nde geliştirilen yarı zamanlı, stajyer ve tam zamanlı personel için geliştirilen üç ayrı mentorluk programının uygulaması ve yapılan gözlemlerin sonucu bu çalışmanın kapsamını oluşturmaktadır. 


\section{Literatür Araştırması}

Veri tabanlarında mentorluk konusunda yapılan aramalarda binlerce makale olduğu görülmektedir. Örneğin, EBSCOHost veri tabanlarından "mentoring" anahtar kelimesiyle yapılan aramada 2000-2011 yılları arasında 19.203 yayın olduğu görülmektedir. Bu yayınlardan 241 'i ise kütüphanelerdeki mentorluk uygulamalarına yöneliktir. Çalışma kapsamında incelenen araştırmalarda mentorluk uygulamasının kütüphanelere olan katkılarının önemli olduğu vurgulanmakta ve personelin eğitiminde kullanılması tavsiye edilmektedir. Türk kütüphanecilik literatüründe ise doğrudan mentorluk konusu ile ilgili yayımlanmış herhangi bir çalışma tespit edilememiştir. Öte yandan Türkçe literatür personel eğitimi konusunda da çok zayıf durumdadır. Türkçe literatürde kütüphane personelinin eğitimi konusuna değinen, İngilizce literatürde ise bu çalışmanın konusuyla doğrudan ilgili olan çalışmaların bir kısmı aşağıda verilmiştir.

Didar Bayır (2007) kütüphane çalışanlarının mesleki gelişimine katkısı bulunan performans değerlendirme çalışmalarını incelediği ve performans değerlendirme çalışmalarına yönelik bilgilerden yararlanarak bir örnek oluşturduğu doktora çalışmasında, yeni işe alınan kütüphanecilerin eğitimi konusuna da değinmiştir. Bu çalışmada "işe alıştırma" başlı̆̆ı altında, yeni kütüphaneciler için üç aylık bir sürede yapılması yararlı görülen uygulama ve davranışlar maddeler halinde belirtilmiştir. Çalışmada, bu tür uygulamaların kurumsal başarının daha kolay yakalanması, kurumun hedeflerinin çalışana aktarılması, insan kaynağı planlamaları yapılması, takım çalışmasını güçlendirmesi, işin kalitesinin arttırılması gibi sonuçları olduğu vurgulanmaktadır.

Holt ve Kızılaslan (2004) üniversite kütüphanelerindeki personelin eğitimine yönelik olarak yaptıkları bir çalışmada "sürekli eğitim" konusunu işlemiş ve Koç Üniversitesi Suna Kıraç Kütüphanesi'ndeki uygulamayı anlatmışlardır. Öte yandan bu çalışma, Türk kütüphanecilik literatüründe mentorluk teriminin kullanıldığı gözlenen ilk çalışmadır. Çalışmada, sürekli eğitim yöntemleri ile çalışanların kendini geliştirmesine katkı sağlandığı ve bunun da kütüphane hizmetlerine olumlu yönde yansıdığı vurgulanmaktadır.

Bülent Yılmaz (2008) halk kütüphaneleri bölge seminerlerine yönelik yaptığı bir çalışma çerçevesinde "hizmet içi eğitim" konusuna değindiğinden dolayı burada belirtilmesinde fayda görülmüştür. Çalışmada, başarılı olmak için personelin sürekli eğitilmesi gerektiği dile getirilmektedir.

Culpepper (2000) akademik kütüphanelerde mentorluk konusunu işlediği makalesinde, mentorluk süreci, mentorluk sürecinden yararlanacak kişiler, mentorların özellikleri, mentorluğun faydaları, mentorluğun kestirilemeyen olumsuz sonuçları ile kuruma ve yeni çalışanlara katkılarını işlemiştir. Çalışmada, kariyer gelişiminde mentorluğun önemli yöntemlerden biri olduğu ileri sürülmektedir. 
Ptolomey (2008) kütüphanecilerin ve kütüphanenin mentorlukla desteklenmesi konulu makalesinde, mentorluk türleri ve tanımlarından bahsettikten sonra uygulanacak mentorluk türünün seçimi, mentorluk sürecindeki yaklaşımlar ile mentorluk süreci için geliştirdiği anahtar sorular ve cevapları vermektedir. Çalışmada, kaliteli mentorluk programları olduğu ve bunların personel gelişiminde fayda sağladığı vurgulanmaktadır.

1993 yılında Dalaware Üniversitesi Kütüphanesi'nde başlangıç niteliğinde olan "tanıtıcı" (6 ay süreli), mesleki beceriyi artırmaya yönelik "kariyer" (6 ay ila 1 yıl süreli) ve profesyonelliği artırmaya yönelik "gelişmiş" (süresi mentor ve danışan tarafından belirlenen) seviyelerinde olmak üzere üç kademeli bir mentorluk programı düzenlenmiştir. Kütüphanedeki mentorluk hizmetinin kurumsallaştırıldığı bu program, kütüphaneciler arasında kendiliğinden gelişen gönüllü mentorluğu engellemeye ya da devre dışı bırakmaya yönelik değildir. Çalışmada, gerçekleştirilen bu uygulamanın yeni personelin gelişiminde beklenenden daha fazla yarar sağladığı vurgulanmaktadır. (Wojewodzki ve diğerleri, 1998, 8). Yine Dalaware Üniversitesi Kütüphanesi'nin İnternet sayfasındaki mentorluk programının 2009 yılı rehberinde, "oryantasyon", "tanıtım" ve "profesyonel" olmak üzere mentorluk programının üç ayrı seviyede düzenlendiği görülmektedir. Oryantasyon mentorluğu programı, yeni kütüphanecilere başlangıç eğitiminin verilmesi ile kütüphanenin ve üniversitenin tanıtılması; tanıtım mentorluğu programı, kariyer tanıtımı ve gelişimi ile kütüphanecilerin tecrübesini pekiştirmeyi amaçlayan belirli gereksinimlere ve hizmetlere odaklanan etkinlikleri; profesyonel mentorluk programı ise, profesyonel ve mesleki gelişim sağlamak, liderlik veya yöneticilik becerisi kazandırmayı amaçlayan etkinlikleri kapsamaktadır (The University of Dalaware, 2009).

Bosch ve diğerleri (2010) makalesinde kütüphaneciler için yenilikçi bir mentorluk yaklaşımı konusu üzerinde durmuşlardır. Kaliforniya Devlet Üniversitesi Kütüphanesindeki mentorluk uygulama çalışmalarının incelendiği makalede, takım oluşturma, lider seçimi, mentor ve danışanın eşlenmesi üzerinde durulduktan sonra, mentor ve danışan perspektifinden modelin değerlendirmesi verilmiş ve takım modeli kaynağının analizi yapılmıştır. Çalışmada uygulanan program ile yeni personelin sosyalleştirilmesi ve kuruma uyumunun hızlandığı belirtilmektedir.

Stueart ve Sullivan (2010) sekiz bölümden oluşan "Developing Library Leaders" adlı kitabın yedinci bölümünde mentorluk konusu üzerinde durmuştur. Mentorluğun tanımı, türleri, fonksiyonları, başarılı mentorluk ilişkileri, mentorun rolleri ve sorumluluklarının açık bir şekilde ele alındığı kitap, bu çalışmanın teorik kısmının oluşturulmasında yol gösterici olmuştur. Öte yandan bu çalışmadaki “Mentor Adayları İçin Öz Değerlendirme” soruları Ek-1'de verilmiştir.

Kuyper-Rushing (2011) üniversite kütüphanelerinde kurumsal mentorluk konusunu işlediği çalışmasında, Lousiana Devlet Üniversitesi Kütüphanesi'nin 1998 yılında geliştirdiği ve uyguladığı mentorluk programını incelemiştir. Programının öncelikli 
amacı, tecrübesiz kütüphanecilerin belli bir program dâhilinde işe uyum sağlamaları, verimliklerinin artırıması, profesyonelleştirilmesi ve ilgi duydukları alanlarda geliştirilmeleridir. Illk yılın sonunda yapılan değerlendirmede, ideal mentorluk ilişkisinin iki birey arasında doğal olarak geliştiği ve Lousiana Devlet Üniversitesi Kütüphanesi mentorluk programının katılımcılara faydalı olduğu görülmüştür. İyi planlanmış ve emek sarf edilmiş bir program olmasının yanında uygulama sürecinin adım adım anlatılmış olması mentorluk programını uygulamak isteyen kütüphanelere yol gösterici niteliktedir.

\section{Mentorluk Kavramı}

Çalışanlar bir kurum için temel kaynaktır ve potansiyellerinin ortaya çıkarılması için kurum bünyesinde gerekli ortam oluşturulmalıdır. Mentorluk, potansiyel yönetimi, kütüphanecilerin potansiyel yeteneklerinin ortaya çıkarılması ve geleceğin liderlerinin yetiştirilmesi için uygun ortam oluşturulmasına aracılık edebilecek bir yöntemdir.

"Mentor" kavramının kökeni Yunan mitolojisine dayanmaktadır. Mitolojiye göre Odysseus, oğlu Telemachus'un eğitiminin sorumluluğunu yakın arkadaşı Mentor'a vermiştir. Bundan dolayı günümüzde "mentor" kavramı, güvenilen ve deneyimli rehber, kılavuz, danışman, akıl hocası ve yol gösterici gibi anlamlarda kullanılmaktadır (Aydın, 2008, 217-218). "Mentor" ve "mentorluk" Türkçe literatürde "hami" ve "hamilik" olarak ifade edilmekle birlikte, bu kavramın "mentor" ve "mentorluk" terimlerini tam olarak karşılamadığı da vurgulanmaktadır (Özkalp ve diğerleri, 2006, 57). Bu bakımdan çalışmada İngilizcedeki karşılı̆ı̆ olan "mentor" kavramı kullanılmıştır.

Deneyimli çalışan ile deneyimsiz ya da daha az deneyimli çalışan arasında bir etkileşim yöntemi olan mentorluk kavramı, "...kurumda destekleyici, pozitif düşünebilen, öğreten ve dinleyen gibi rolleri üstlenerek bireyin kuruma kazandırılması ve kariyer gelişimine yardımcı olunması konusunda danışmanlık yapan, ona rehber olan kişidir.." Deneyimsiz ve daha az deneyimli çalışanı ifade eden "danışan" (mentee/ protégé) kavramı ise "...kuruma yeni katılan elemanlardan ya da potansiyel taşıyan yönetici adaylarından oluşur. Bunlar başarılı olmayı amaçlayan, kurum aidiyetini, kurum kültür ve politikasını kazanması gereken, kariyer hedeflerine ulaşmak için profesyonel yardım bekleyen kişilerdir." (Uçkun ve Kılınç, 2007, 77) şeklinde ifade edilmektedir.

Mentor, tecrübesiz çalışanların kendisini geliştirmesine ve iyileştirmesine yardımcı olan tecrübeli çalışanlardır. Mentorluk, deneyimli bir kütüphanecinin daha az deneyimli bir kütüphaneciye sürekli destek vermesi olarak düşünülebilir. Mentorluk bir denetleme biçimi değil, yol gösterici ve yararlı bir uygulamadır. Mentor ile mentorluk uygulamasından yararlanan kişi/kişiler arasındaki her türlü etkileşim tam bir güvene dayalı olmalıdır. Mentor, sorduğu sorularla danışan kişinin, hedefine ulaşmasını sağlayacak yolu bulmasına yardımcı olur. 
Mentorluk bireyler arasında kapalı bir ilişkidir (Culpepper, 2000, 72) ve danışanların sahip olduğu yeteneklerini istenilen yönde değişim ve gelişimini sağlamak üzere yapılan yol gösterme uygulamasıdır (Özkalp ve diğerleri, 2006, 56). Farkındalık yaratmak, geliştirmek, anlatmak, deneyim aktarmak, yönlendirmek, şeklinde ifade edebileceğimiz mentorluk yaklaşımının iş yaşamında uygulaması kritik bir öneme sahiptir. Bu yaklaşım, kıdemli ve başarılı çalışanlara yeni bir kariyer fırsatı yaratırken, deneyimsiz çalışanların, kıdemli ve deneyimli çalışanlar tarafından iş başında yetiştirilmelerine olanak sağlar. Öte yandan mesleğe yeni başlamış çalışanlar için çok önemlidir ve onların mesleki bir kimlik oluşturmalarına yol göstereceği gibi verimliliklerinin de artmasına katkı sağlar.

İlk defa bir işe giren veya yeni bir işe başlayanların kuruma uyum sürecinde ona rehberlik edecek tecrübeli bir çalışan görevlendirilir. Bu kişi yeni çalışana akıl hocalığı yapar, destekler, yol gösterir. Yani mentorluk yapar. Bu süreçte, işin içeriği, çalışanlar ve birimler ile ilgili bilgi verilir. Ardından kurumun, misyonu, vizyonu, değerleri, kültürü yeni çalışana aktarılır. Bu işi yapan tecrübeli çalışan mentorluk görevini yerine getirir. Dolayısıyla mentorun seçimi, yeni çalışanın iyi bir başlangıç yapması bakımından çok önemlidir.

Sürekli değişen ve gelişen bilgi teknolojisini takip etmek, elektronik otama göç eden bilgi kaynaklarından en üst düzeyde yararlanmak ve bunları bilgi hizmetlerine yansıtmak kütüphaneler açısından çok önemlidir. Belli bir başarıyı yakalamış kütüphanelerde hedeflerin sürekli büyütülmesi ve bu hedeflere ulaşılmasında tecrübeli çalışanlardan yararlanılması bakımından mentorluk uygulaması önemli bir süreçtir. Sahip olduğu tecrübe ile sağlıklı karar verebilen, bilgi teknolojisindeki yenilikleri takip edebilen, özgüveni yüksek, yaratıcı, girişimci, mentorluk özelliklerine sahip çalışanların katkılarıyla kütüphaneler arzulanan bilgi hizmetini en üst düzeyde verebilirler.

\section{Mentorluk Yaklaşımları ve Türleri}

Mentorluk, iş yaşamında çalışanın disiplinli bir şekilde eğitilmesi bakımından "mesleki gelişime" ve çalışanda farkındalık yaratmak ve hedeflerine ulaşmasını sağlamak bakımından "kişisel gelişime" odaklanan iki modelden oluşur. Bu süreçte mentor deneyimini aktarırken, mentorluk hizmetinden yararlanan ise kendini geliştirir (Uçkun ve Kılınç, 2007). Mentorluk uygulaması, bireysel çaba, birlikte öğrenme, paylaşım ve fikir birliği için önemli bir fırsattır. Mentorluk onur verici bir görevdir ve iyi bir mentor, mentorluk ilişkisinden beklenen faydanın sağlanabilmesi için güven verici bir ortam oluşturmalıdır. Mentorluk ilişkisi kimi riskleri de beraberinde getirebilir. Çünkü mentorluk gerçek ve özgün bir uygulama olduğundan sadece başarılar değil, başarısızlıklar da paylaşılır.

Gönüllü ve kurumsal olmak üzere iki tür mentorluk yaklaşımı vardır (Ptolomey, 2008, 310; Stueart ve Sullivan, 2010, 72-73). Birincisi kişisel gelişimin bir parçası olarak tecrübeli ve genç meslektaşlar arasında kendiliğinden gelişen "gönüllü mentorluk", ikincisi 
ise kurumlarda personelin eğitimi, gelişimi ve yeteneklerinin ortaya çıkarılması için planlanmış bir süreç olarak gelişen "kurumsal mentorluk"tur. Günlük çalışmalar sırasında meslektaşlar arasındaki arkadaşlık ve bilgi paylaşımı çerçevesinde kendiliğinden gelişen gönüllü mentorluk süreci hem genç çalışanların hem de kurumun gelişimine katkı sağlar. Gönüllü mentorluk hemen hemen tüm kurumlarda kendiliğinden gelişen, kuruma ve genç çalışana katkı sağlayan ve belli bir düzeni olmayan mentorluk türüdür (Stueart ve Sullivan, 2010, 74). Gönüllü mentorluk uygulaması kurumsal mentorluğa göre daha etkin bir yöntemdir. Gönüllü mentorluğun ast-üst ilişkilerini olumsuz yönde etkilemesi, istenmeyen duygusal sonuçlarla karşılaşııması, mentorun danışanı sahiplenerek koruma eğilimine girmesi, danışanın mentorun önerileri ve tavsiyeleri dışına çıkması gibi çeşitli olumsuz yönleri de vardır (Uçkun ve Kılınç, 2007, 90; Stueart ve Sullivan, 2010). Mentorluk ilişkileri karşılıklı öğrenmeyi sağlayan bir süreçtir ve mentorluk programları faydalı süreçler olarak tasarlanmalıdır. Gönüllü veya kurumsal olarak uygulanan mentorluk ilişkisi içinde ters yönde mentorluk ilişkisi de oluşabilir. Böylece yeni bilgi teknolojilerine hakim genç çalışanlar, yetişkin personele bu yolla bilgilerini aktarır (Murphy, 2008, 436).

Gönüllü mentorluk kurumsal mentorluğun aksine tecrübeli çalışan ile genç çalışan arasındakendiliğindengelişir.Kütüphanelerdegönülümentorluğunönemizamaniçinde anlaşılmış ve kabul görmüştür. Tecrübeli çalışanların ortak mentorluk etkinlikleri, bireysel kariyer başarısının olumlu bağlantılarını oluşturmuş ve bu da kurumsal mentorluğun gelişmesine katkı sağlamıştır (Stueart ve Sullivan, 2010, 72-75). Kütüphanelerdeki çoğu kurumsal mentorluk programları, yeni kütüphanecilerin uzmanlaşması sürecinin daha önceden belirlenmiş programlar çerçevesinde sürdürülmesi için oluşturulmuştur (Murphy, 2008, 435). Tamamlayıcı bir mentorluk etkinliğinin temel stratejisi, kurumsal program ve mentorun niteliği aracılığıyla kurumlarda başarıya ulaşmak veya başarıyı korumak, kariyer gelişim sürecini değerlendirmek, danışanın sistematik gelişimini sağlamaktır. Bu yaklaşım sayesinde danışan, mentorun gözetiminde iş doyumu sağlar, mentorun tecrübesi ve uzmanlığından faydalanır, kütüphanelerin başarısı ve saygınlığının artmasına katkıda bulunur (Stueart ve Sullivan, 2010).

Uçkun ve Kılınç $(2007,91)$ mentorluk programı süresini en kısa 18 ay, en fazla 3 yıl olduğunu ve aksatılmadan sürdürülmesi gerektiğini belirtmektedir. Kütüphanecilik alanında uygulanan mentorluk programları ise genellikle 6 ay ila 1 yıl sürelidir ve çeşitli seviyelerde düzenlenen, birbirini takip eden bir mentorluk programı yapısı söz konusudur (Wojewodzki ve diğerleri, 1998; Kuyper-Rushing, 2011, 442; Bosch ve diğerleri, 2010, 64).

Büyük kuruluşlarda, faklı kültür, köken, meslek vb. özelliklerden dolayı mentorluk uygulamaları kolay olur ve daha iyi sonuçlar alınır. Mentorluk uygulaması yoğun iş temposu içinde uygulanacağından mentor ve bu uygulamadan yararlanan çalışanların gönüllü olması istenilen yararın elde edilmesi bakımından önemlidir. Mentorluk alacak 
bireyler amaçlarını iyi belirlemelidir. Mentor ise sahip olduğu birikimleri paylaşırken tecrübesini daha da artıracağının bilincinde olmalıdır. Mentorluk uygulamasındaki bir diğer önemli husus ise güven ilişkisidir. Mentor ve mentorluk hizmeti alanlar belirlenirken bu hususa dikkat edilmelidir. Mentorlukta önemli aşamalardan biri de mentor ve danışanların eşleştirilmesidir. Bu eşleştirmede öncelik mentorluk hizmeti alacak olan kişide olmalıdır (Uçkun ve Kılınç, 2007, 91).

Tüm kurumlarda olduğu gibi kütüphanelerde kurumsal başarı için personel gelişimi öncelikli faktördür. Kurumlarda gelişimin devamı ve kurumların doğru yönlendirilmesinde en önemli kaynak personeldir. Personelin eğitilmesi ve geliştirilmesinde etkili yollardan biri de mentorluktur. Kurumlarda motivasyon, takım çalışması, teşvik edici öğrenme, kariyer gelişimi ve lider gelişimini desteklemek için mentorluk programı faydalı sonuçlar vermektedir (Stueart ve Sullivan, 2010).

Kütüphanelerde kurumsal mentorluk etkinlikleri eskisine göre daha yapısaldır ve bireyin profesyonel gelişimi için rol modelden faydalanılır. Bu tür mentorluk etkinlikleri, kurumun bir çalışanı nitelik ve yetkinliklerini rol model olarak gösterdiğinde, çoğunlukla kurumsal bir yapı veya planlanmış bir süreç dışında örnek lider özelliğinden oluşur. Mentorluk, mentor için profesyonel bir kazanç olmadığı gibi tek tip insan yetiştirme yaklaşımı da değildir. Danışanın profesyonel gelişimini yönetmek de değildir. Personel ve kurumun gelişmesi için meslektaş etkileşmesidir. Mentor, bir kişinin sahip olduğu özellikleri, karakteri ve yeteneğini öngörüleriyle ortaya çıkarmasına aracılık eder. Mentorluk "rol model", "öğretmen", "rehber" ve "bilge"liğin karakteristik özelliklerini içerir. Mentorluktan yararlanan bir çalışan samimi bir ortamda yeteneklerinin gelişimini sağlayarak kazanç elde eder (Stueart ve Sullivan, 2010, 73).

Çoğu durumda mentorluk sürecinden sağlanması beklenen faydanın temel nedeni benzerdir. Yani kurumsal mentorluk programı süreci, mentor ve danışan arasındaki gönüllü mentorluk sürecinde karşılıklı ilginin paylaşımıdır. Bu herkesi kapsayan bir öğrenme sürecidir ve kişilerarası beceri ve mentorun uzmanlığını tanımadır. Ayrıca genç meslektaşların gelişim sürecinde mesleki yetkinliklerini geliştirmesinin etkili bir yoludur. Böyle başarılı ilişkilerin kurulmasıyla iki meslektaşın mentorluğa başlaması bir profesyonel rol model olarak mentorun tanınması ve saygı görmesinde etkili bir yoldur.

Eskiden mentorluk erkek egemen, genellikle kariyer odaklı, mentor ve danışanın yarar sağlamasına odaklanan bir etkinlikti. Geleneksel anlamda genç meslektaşların, yetişkinlerin arasına katılma süreci olarak ifade edilebilecek bir yaklaşımdı. Mentorluk bu yaklaşımdaki kalıplaşmış çoğu etkinliği değiştirdi. Bugün kütüphaneler sürekli artan bir eğilimle mentorluk etkinlikleri ile yenilikçi yaklaşımları benimsemekte ve kurumsallaşmaktadır. Bunun öncelikli nedeni tanıtım, varlıklarını sürdürme, dinamik bir yapı oluşturma ve geleceğin liderlerini yetiştirmedir. Diğer nedeni ise çalışan ve kurumun yararı için mentorluk kültürünü yaygınlaştırmak, öğrenen organizasyonları teşvik etmek, çalışanın performansını artırmak ve motivasyonu yükseltmek şeklinde 
ifade edilebilir. Mentorluk süreci, mentor kelimesinin harfleriyle ifade edilen analitik bir süreç olarak kabul edilebilir: MENTOR= Model (model), Empathize (hissetme), Nurture (yetiştirme), Teach (öğretme), Organize (düzenleme), Respond (cevap) (Stueart ve Sullivan, 2010, 74).

Mentorluk ve koçluk benzer uygulamalar olmasına rağmen çoğunlukla birbirine karıştırılır, ancak farklı uygulamalardır. Koçluk, koçluk hizmeti alanların performansını artırmak için resmi gözlem ve geri dönüş sağlar. Bir koç ve bir mentorun ortak yönleri ise benzer teknikleri, becerileri, birincil iletişim yollarını ve kişilerarası becerileri kullanarak meslektaşlara yardım etmesidir. Bu nedenle çoğu durumda etkili mentorlar koçluk becerilerini kullanılırlar. Gerek koç gerek mentor, sorduğu sorularla danışan kişinin, hedefine ulaşmasını sağlayacak yolu bulmasına yardımcı olur. Koçluk ve mentorluğun farkı Şekil 1'deki gibi ifade edilebilir (Navitas Eğitim, 2010).

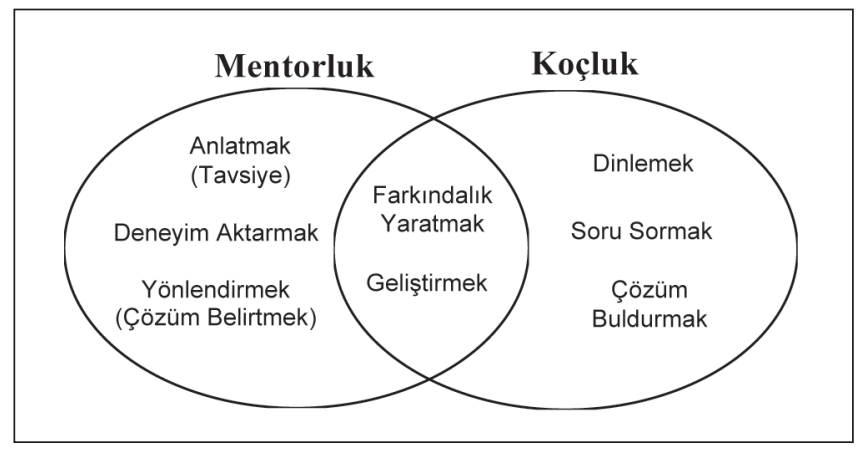

Şekil 1. Koçluk ve Mentorluğun Farkı

Mentorluğun yüz-yüze, bire-bir yaklaşım gibi çeşitli şekilleri vardır. Bunlardan bazıları aşağıda kısaca belirtilmiştir (Stueart ve Sullivan, 2010, 81-82):

1. Grup mentorluğu, bir danışan için birden çok mentorun yer aldığı mentorluk yaklaşımıdır. Danışan bu mentorluk yaklaşımıyla farklı bireysel bilgi ve uzmanlıkları olan mentorların tecrübe ve bilgisini paylaşma avantajından yararlanır.

2. Çember-grup mentorluğu, birden çok danışan ve her biri ayrı uzmanlık alanına sahip mentorun olduğu mentorluk türüdür. Birden çok danışan, mentorların tecrübesinden ve uzmanlığından yararlanır. Ayrıca bu yaklaşım bir kurumda yeteri kadar mentor olmaması durumunda programın yürütülmesini kolaylaştıran bir mentorluk türüdür.

3. Akran mentorluğu, kurumsal veya gönüllü olarak gelişen mentorluk türüdür. Genellikle kişisel olarak düzenlenir ve gurup üyelerinin uzmanlığından yararlanma 
avantajı sunar. Geleneksel hiyerarşik mentorluk ilişkilerine bir alternatif olarak kabul edilebilir. Belli bir gruba yönelik olmayan bu mentorluk türü tüm uygulamalarda, çeşitli seviyelerde kullanılabilir. Öte yandan bu ilişki içinde olanları psikolojik yönden de destekleyen bir uygulamadır.

4. E-mentorluk, elektronik ortamdaki iletişim kanallarıyla gerçekleştirilen mentorluk türüdür. Her geçen gün gelişmekte ve yaygınlaşmakta olan bu mentorluk türünde zaman ve mekân sınırlamasının olmaması önemli bir avantajdır.

5. Ters mentorluk, genç çalışanın, yetişkin çalışana destek olduğu mentorluk türüdür. Özellikle bilgisayar, internet gibi bilgi teknolojisi araç ve gereçlerin kullanımı gibi konularda görülen mentorluk türüdür.

\section{Mentorluğun Fonksiyonları ve Mentorluk ilişkisi}

Mentorluk programlarının başarısı, mentor ve danışanların istekliliğine ve sorumluluklarını kabul etmesine bağlıdır (Wojewodzki ve diğerleri, 1998, 6). Mentorlar sorumlu oldukları çalışanların gelişimini teşvik eden başarılı rol modelleridir. Sorumlu oldukları deneyimsiz çalışanın gelişimi için gerekli olan bilgilendirme ve yönlendirmeleri yapar. Mentorlar sorumlu oldukları çalışanın yeteneklerinin etkin kullanımını sağlamak için çalışır ve gelecekte alacağı sorumlulukları düşünmeye teşvik eder (Culpepper 2000, 76).

Kurumlar personelin mesleki ve sosyal yönden gelişimi için mentorluk programları geliştirmektedir. Kurumsal başarıda iş ortamının \%33 payı vardır ve bu ortam da \%75 oranında yöneticiler tarafından belirlenmektedir. Bu nedenle kurumlar tecrübeli çalışanlarından mentorluk programları çerçevesinde yararlanarak genç çalışanları eğitime ve geliştirme yoluna giderek verimliliklerini artırmak çabasındadırlar (Uçkun ve Kılınç, 2007, 92). Kurumsal mentorluk programları biçimlendirilmiş programlardır. Belli amaç, hedef ve beklenen sonuçları içerir. Kurumsallaşmış mentorluk programlarında katılımcılar, deneyimli mentorlarla birlikte kariyer gelişimlerinin sağlanması, uygulama ve yönetim becerilerinin geliştirilmesi, zayıf yönlerinin güçlendirilmesi ve geliştirilmesi bakımından eşleştirilir. Kurumsal olmayan diğer programlarda ise amaç ve hedefler biçimsel bir yapı olmadan, doğal olarak gelişen bir yapı çerçevesinde oluşur.

Kurumların başarısı için personel gelişimi çok önemlidir. İyi hizmet veren kütüphanelerde başarıya ulaşmak için personelin geliştirilmesi bir odak noktası haline gelmiştir. Ayrıca mentorluk yoluyla personel ve dolayısıyla organizasyonların gelişimi, buna bağlı olarak hizmet kalitesinin artmasında mentorluk uygulamaları bir araç haline gelmiştir. Mentor ve mentorluk programından yararlanan kişi, mentorluk ilişkisinin başlangıcında amaç, hedef ve kabul edilebilir sonuçların ne olacağını iyi irdelemelidir. Bu nedenle, amaç, iletişim, süreç ve geribildirim hususlarında fikir birliği yapılmalıdır (Stueart ve Sullivan, 2010, 75-76): 
1. Amaç: Birlikteliğin nedeni ve programdan beklentiyi ifade eder.

2. İletişim: İletişim için yüz yüze, telefon, e-posta, kısa mesaj vb. gibi araç veya yöntemlerden hangisinin tercih edileceğini ifade der.

3. Süreç: Kurumsal mentorluk sürecinde planlama, yapısal ilişki oluşturma, görüşerek anlaşma, mentorluk alan kişinin gelişimi ve değerlendirmesini ifade eder.

4. Geribildirim: Olumlu ve düzeltici geri bildirimleri ifade eder.

Kurumlardaki mentorluk gelişim süreci çeşitli fonksiyonlara sahiptir. Mentorluk, danışanın mesleki yetkinliklerini artırmak için iyi bir yoldur. Kütüphanelerde yeni personelin çalışma düzenine uyumu ve bilgi hizmetlerinin amacına ulaşmasını hızlandırır. Kurumsal olarak kabul görmüşsüreçlerde deneyimsiz personelin gelişiminin izlenmesi, bireysel ve kurumsal gelişim sürecinde önemli katkılar sağlar (Stueart ve Sullivan, 2010).

Kram (1983, 614) mentorluk fonksiyonlarını kariyer ve psiko-sosyal olarak iki gruba ayırmaktadır. Bu iki grubun fonksiyonlarını ise Tablo l'de verildiği şekilde ifade etmektedir.

Tablo I. Mentorluk Fonksiyonları

\begin{tabular}{cc}
\hline Kariyer Fonksiyonları & Psiko-Sosyal Fonksiyonlar \\
\hline Destek olma & Rol model \\
Kendini ifade etme - Görünür kılma & Kurumda kabullenme - Benimsenme \\
Bilgilendirme & Danışman \\
Koruma & Arkadaşlık \\
Becerileri geliştirecek görevler verme & \\
\hline
\end{tabular}

Kram'a $(1983,614)$ göre başarılı bir mentorluk ilişkisi; Şekil 2'de görüleceği üzere mentorluk ilişkisinin başladığı “başlangıç aşaması”, kariyer ve psiko-sosyal fonksiyonların en üst düzeye ulaştığı "yetiştirme aşaması”, karşılıklı psiko-sosyal değişimlerin yaşandığı ve ilişkinin beklentileri karşılamadığı düşüncesiyle gerçekleşen "ayrılma aşaması", taraflar arasındaki ilişkinin olgunlaştığı, kimi zaman mentorluk ilişkisinin ötesine geçtiği "yeniden tanımlama aşaması" olmak üzere dört aşamadan oluşur. 


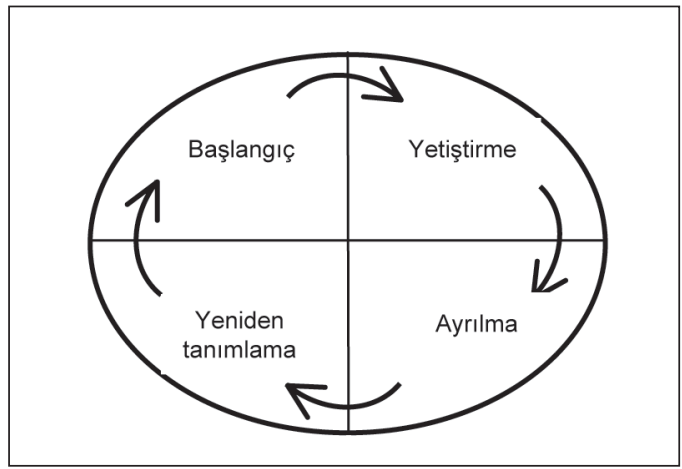

Şekil 2. Mentorluk İlişkisi

Genç meslektaşların gelişiminde mentor-danışan iliş̧isinin kritik bileşeni "dinleme" faaliyetidir. Kütüphanelerdeki mentorluk programlarının yapısında zaman süreci olmalı, mentor ve danışan arasında bir eşleştirme yapılmalıdır. Eşleştirmede, mentorluk sürecine katılacakların uzmanlıkları, kişisel özellikleri, yetenekleri ile kurumun gelecekteki potansiyel ihtiyaçlarına dikkat edilmelidir (Uçkun ve Kılınç, 2007, 91).

Bir mentor-danışan programı aşağıdaki adımları içerir (Stueart ve Sullivan, 2010, 7778):

1. Kurumun misyonu, amaç ve hedefleri ile mentorun uzmanlık alanını esas alınarak mentor ile danışan eşlenir.

2. Mentor ve danışanın süreçten beklentileri tanımlanır (program süresi, görüşme yeri, mentor ve danışan arasındaki etkileşim, değerlendirme formları, olumsuzlukların belirlenmesi vb.)

3. Bir sözleşme düzenlenerek imzalanır. Kurumsal mentorluk programları değerlendirme yapmaya zemin oluşturacak sözleşmeler ile düzenlenir ve bu sözleşmeler etkinliklerin gelişimi için bir rehber niteliğindedir. Katılımcılar için bir rehber olan sözleşmeler, toplantı zamanları ve yerlerini, destekleyici etkinliklerin yanı sıra mesleki toplantılar, belli konulardaki konferanslar gibi etkinlikleri de içerebilir. Ayrıca sözleşmede gelişim hedefleri ve ulaşılması hedeflenen başarı noktasını da içerir.

4. Mentor ve danışan arasındaki gizliliği korur.

5. Mentorluk süreci tamamlandığında bir değerlendirme yazılarak üst yönetime sunulur. 


\section{Mentorun Özellikleri ve Rolleri}

Danışanlar başarılı olmayı amaçlayan, kurum kültürü ve politikasını kazanması gereken ve profesyonel desteğe ihtiyacı olan kişilerdir (Uçkun ve Kılınç, 2007, 77). Mentor kurumun önemli bilgi ve tecrübeye sahip yetişmiş bir üyesi olmanın yanında amaç, hedef, politika ve süreçlerini bilen, çalışana rehberlik eden rol modeldir (Özkalp ve diğerleri, 2006, 57). İyi bir mentor bazı özelliklere sahip olmanın yanında meslektaşlarıyla iyi iletişim kurma becerisine sahip kişilerdir (Stueart ve Sullivan, 2010, 75). İnsan ilişkileri kuvvetli, açık fikirli, esnek ve empatik yapıya sahip olması gereken bir mentorun özellikleri şu şekilde sıralanabilir (Aydın, 2008, 219; Uçkun ve Kılınç, 2007, 81-82);

1. Kuruma karşı olumlu tutum ve doğru iş alışkanlıkları,

2. Yüksek performans,

3. Özgüvenli ve yeterli iş deneyimi,

4. Yardım sever ve saygılı,

5. Sabırlı ve hoşgörülü,

6. İnsan odaklı ve hayatla barışık,

7. Esnek ve yaratıcı,

8. İletişim kurabilen, aktif, empatik ve duyarlı.

Mentorlar danışanların yaptığı işin kalitesini kontrol etmezler. Mentorlar, mentorluk sürecinde en iyi yaklaşım yolunu gösterir, gerekli dokümanları hazırlar, fırsatların belirlenmesine aracı olur ve teşvik eder (Wojewodzki ve diğerleri, 1998). Mentorluk, potansiyel mentor davranış ve becerilerini artırmak için iyi bir yoldur. Başarılı bir mentorluk ilişkisinde beklentiler ve ihtiyaçların açıkça ortaya konması için mentor ile danışanlar arasında güven duygusunun gelişmesi gerekir. Açıklık, karşılıklı güven hissinin oluşmasıyla doğrudan ilişkilidir. Bir mentorluk ilişkisi içinde her şey karşılıklı güvene dayalıdır ve güven, mentorluk ilişkisinin temelini oluşturur.

Mentorlardaki iyi bir dinleyici olma özelliği, danışanın uygulamadaki tecrübe ve gözlemlerindeki endişelerinin belirlenip giderilmesini sağlar. Dinlemedeki empatik davranışlar ast-üst ilişkisinde açıklığı ve danışanın karşılaştığı sıkıntıları rahatça paylaşmasını sağlar. Danışanı dinleme, uygun eleştiri yapma mentorun öncelikli görevleri arasındadır. Mentorlar danışanın tecrübesizliğini ve hatalarını anlayışla karşılamalıdır. Öte yandan mentorlar da kendilerinin mükemmel olmadıklarını ve öğrenmenin sonunun olmadığını kabullenmelidir. Mentorluk sürecinde bir diğer önemli husus ise kişisel değerlerin belirlenmesidir. Mentor ile danışan ilişkisinde mentorların rolü şu şekilde sıralanabilir (Stueart ve Sullivan, 2010, 80); 
1. Illetişim için etkileşimli bir çevre, teşvik edici yönlendirme ve bilgi paylaşımı,

2. Beceri ve kariyer hedefi gelişimi yaklaşımında öneri,

3. Terfi fırsatları içinde danışan faaliyetlerinin temsil edilmesi,

4. Danışan yeteneklerinin gelişimi ve tanıtılması,

5. Danışanın eğitimde ve diğer alanlarda teşvik edilmesi.

\section{Başarılı Bir Mentor-Danışan İlişkisi İçin Anahtar Faktörler}

Kütüphanelerde mentorluk uygulaması, tecrübeli kütüphaneciler ve genç kütüphaneciler için yeni bir derece veya yeni bir görevin alınması, değerli tecrübeler kazanılmasını sağlar. Bir çalışma arkadaşı veya mentorun iş yerinde işle ilgili sıkıntıların aşılması için genç çalışanlara yardımcı olması hem tecrübesiz çalışana hem de kuruma önemli katkılar sağlar (Lee, 2009). Mentorlar, mentorluk sürecinde lider olarak itibar ve becerilerini artırırlar. Mentorluk sürecinde ve sonrasında gönüllü olarak devam eden mentorluk ilişkisinin önemli öğelerinden biri olan danışanlarının güven ve saygısı ise mentorlara ilham verir ve başarılı bir mentorluk ilişkisinin anahtar faktörüdür (Wojewodzki ve diğerleri, 1998; Uçkun ve Kılınç, 2007). Bu güven ve saygı hem mentorluk sürecini yeni tamamlayan kütüphanecilerin mentorlarından zaman zaman yardım alması suretiyle daha da profesyonelleşmesine hem de mentorların yeni kütüphanecileri yetiştirme isteklerinin artmasına neden olur.

Genç çalışanların gelişim sürecine destek veren mentor, danışman, uzman, rol model ve genellikle meslektaştır. Bir mentorluk ilişkisinde, danışan problemlere çözüm arar, sorunları paylaşır ve mentordan öneriler alır. Ancak mentorun öncelikli sorumluluğu amaç ve hedefleri belirlemektir. Amaçların düzenlemesi kritik öneme sahiptir ve amaçlar programın yapısını içerir. İyi düzenleniş amaçlar birlikte iş yapmaya ve belli konuları ön plana çıkartmada rehberlik eder. Mentor amaçları belirlemenin yanında danışanın amaç belirlemesine katkı sağlar ve becerilerin gelişimi için danışana yardım eder (Stueart ve Sullivan, 2010, 81).

Bir öğrenme sürecinin sağlıklı yürüyebilmesi için geri bildirimler çok önemlidir. Bu bakımdan mentorluk programları katılımcıların mevcut sorumluluklarını aksatmadan sürdürebilmelerine izin verecek bir esnekliğine sahip olmalıdır. Katılımcıların birbirine ulaşımı ve geri bildirimler çok önemlidir; çünkü beklentilerin ne oranda gerçekleştiğini değerlendirebilmek için geri bildirime ihtiyaç vardır. Geri bildirimler yoluyla danışanın sistematik öğrenmesi ve gelişmesi sağlanır. Yazılı bir plan, sürecin yürütülmesinde en etkili yoldur. İlişkideki bu önemli yaklaşım mentorun profesyonel bütünlüğünü ve bilgisini gösterir. Danışan bu yaklaşımdan etkilenebilir, örnek alabilir ve ona göre bir yol haritası belirleyebilir. 


\section{Doğuş Üniversitesi Kütüphanesi Mentorluk Programı}

Eğitim-öğretim ve araştırma programlarını desteklemek, ulusal ve uluslararası ölçekte bilgi birikimi, kullanımı ve transferine katkı sağlamak amacıyla 1995 yılında koleksiyonu oluşturulmaya başlanan Doğuş Üniversitesi Kütüphanesi, 1997 yılında üniversitenin kurulmasıyla birlikte faaliyete geçmiştir. İstanbul, Kadıköy'de bulunan Doğuş Üniversitesinde 4035 öğrenci, 471 öğretim üyesi/görevlisi vardır. Türkçe ve İngilizce dillerde eğitim ve öğretimin yapıldığı üniversitenin kütüphanesinde; 83.500 civarında kitap (26.000 basılı, 57.500 elektronik), 24.000 civarında dergi (300 basılı, 23.700 elektronik) ve 800 civarında görsel-işitsel (DVD, VCD, CD ve ses kaseti) bilgi kaynağı vardır. Kütüphane hizmetleri 3 kütüphaneci, 1 memur ve 3 yarı zamanlı öğrenci ile verilmektedir.

Doğuş Üniversitesi Kütüphanesinde mentorluk programı ilk defa, Bilgi ve Belge Yönetimi bölümlerinden, üniversite kütüphanesi stajı yapmak üzere gelen iki öğrenci için Temmuz-Ağustos 2010 tarihinde deneme amaçlı uygulanmıştır. Kütüphane müdürü tarafından yürütülen mentorluk programında öğrencilerin doğal davranabilmesi için gerekli koşullar ve iletişim ortamı oluşturulmuştur. Stajyerlerin teorik olarak öğrendikleri bilgileri en üst düzeyde uygulama tecrübesi yaşamaları için program staj süresince devam ettirilmiştir. Uygulama sonundaki başarı, işe yeni alınan bir kütüphaneci ile bir memur için programın genişletilmiş şekilde uygulanması hususunda önemli geri dönüşler sağlamıştır. Kütüphaneci ve memur olarak göreve başlayan çalışanların mentorluk görevi hem müdür hem de müdür yardımcısı tarafından üstlenilmiş ve 6 aylık bir program Eylül 2010 tarihinde uygulanmaya başlanmıştır. Öte yandan yarı zamanlı olarak çalıştırılan öğrenciler için de Ekim 2010 tarihinde iki hafta süreli mentorluk programı uygulaması düzenlenmiş ve uygulanmıştır.

Program süresi stajyerler için staj süresince, yarı zamanlılar için iki hafta, çalışanlar için bir yıl olarak planlanmıştır. Stajyerler için program, stajyerliğin amacına uygun olarak staj süresince uygulanmıştır. Yarı zamanlılar için uygulama süresinin kısa tutulması, onların görev alanlarının sadece raf okuma, kaynak bulma ve yerleştirme, kitapların içindekiler sayfası ve kapaklarının taranması gibi konularda sınırlı sorumluluklarının olmasından kaynaklıdır. Personel için mentorluk programı süresi 6'şar aylık iki dönem halinde planlanmıştır ve ilk dönemde her ay bir durum değerlendirmesi yapılarak uygulamanın faydalı olup olmadığı değerlendirilmiştir. İlk dönem sonunda faydalı olduğu gözlenen programın ikinci dönemine devam edilmesi kararı verilmiştir ve bu dönem için dönem sonunda ve gerek duyulması halinde değerlendirme toplantısı yapılması kararlaştırılmıştır.

\section{Yarı Zamanlı Personel Mentorluk Programı}

Yarı zamanlı personele yapılan mentorluk uygulaması ile daha önceden işe uyum için harcanan 5 haftalık süreç, program sayesinde 2 haftada gerçekleştirilmiştir. 
Yapılan işin amacını anlayan yarı zamanlı personelin motivasyonu artmıştır. Yapılan değerlendirmelerde bir önceki yıla göre yarı zamanlı personelin performansının \%50 civarında arttığı gözlenmiştir. Üniversitedeki genel uygulama çerçevesinde yarı zamanlılar sadece bir yıl süreyle çalıştırılmaktadır, ancak bu mentorluk uygulamasını akran destek hizmetiyle beslemek için mevcut çalışanlardan en azından birisinin bir sonraki yıl göreve devam etmesi kararlaştırılmıştır. Yarı zamanlı personel için iki haftalık sürede Tablo II'deki program uygulanmaktadır.

\section{Stajyer Öğrenci Mentorluk Programı}

Kütüphanecilik alanında öğrenim gören öğrencilerin iyi yetişmesine katkı sağlamak bakımından her yıl en az bir stajyer öğrenci alınarak bu program çerçevesinde staj yaptırılması kararlaştırılmıştır. Öte yandan stajyerlere harcanacak emek ve zamanın boşa gitmemesi bakımından da ön görüşme yapılarak, kütüphaneci olmaya istekli olanların alınması ve planlanan mentorluk programı çerçevesinde staj yapmaya istekli olup olmadığının belirlenmesi yönünde fikir birliği oluşturulmuştur. Bu çerçevede 2010 yılında iki kütüphanecilik bölümü öğrencisine staj yaptırılmıştır. Kütüphane müdürünün ve yardımcısının gözetiminde stajyerlere Tablo II'de belirtilen program uygulanmıştır.

\section{Personel Mentorluk Programı}

Sınırlı sayıda personel ile kütüphane uygulama ve hizmetlerinin yürütülmesi, öncelikle yeni personelin ve mevcut personelin faklı alanlardaki uzmanlıklarının hızla geliştirilmesi zorunluluğundan kaynaklı arayışlar sonucunda mentorluk uygulaması yapılmasının faydalı olacağı fikri oluşmuştur. Bu fikrin karara bağlanmasında stajyerlere uygulanan program önemli ölçüde etkili olmuştur. Öte yandan mentorluk programı uygulamasının, personel eğitimine önemli katkıları olan kongre-konferans-seminer gibi etkinliklere, üniversitedeki hizmet içi eğitimlere ve çeşitli firmalar tarafından gerçekleştirilen eğitim toplantılarına katılım sağlanması yanında, mesleki yayınların izlenmesi ve değerlendirmesinin yapılmasıyla desteklenmesi hedeflenmiştir. Bu nedenle işe yeni alınan personele Tablo II'deki uygulama ve hizmetlerin mentorluk uygulaması çerçevesinde aktarılarak, onların geliştirilmesi ve en kısa sürede verimliliklerinin artırılması hedeflenmiştir. Uygulama sırasında notlar alınmış, personelin zayıf olduğu konular üzerinde daha fazla durulmuş, önerler dikkatle dinlenmiş ve gerekli olduğu düşünülen değişiklikler programa yansıtılmıştır. Tam zamanlı personele uygulanan mentorluk programı ilk dönem sonunda gözden geçirilmiş ve son şekli Tablo II'de verilmiştir.

Tablo Il'de görev tanımları için Doğuş Üniversitesi Kütüphanesinde uygulanan mentorluk programlarına mentorların katılımı gönüllü, danışanların katılımının ise zorunlu olmasının uygun olacağına karar verilmiştir. İşe yeni alınanlar, kendinden daha tecrübeli olanlarla birlikte daha verimli ve kısa sürede kendini geliştirebileceğinin bilinciyle, mentorlar ise yeni personelin en kısa sürede istenilen düzeye erişip, görev 
Tablo II. Doğuş Üniversitesi Kütüphanesi Mentorluk Programı

\begin{tabular}{|c|c|c|c|c|}
\hline Görev Tanımı & $\mathbf{K}$ & M & $\mathbf{s}$ & YZ \\
\hline Üniversite ve kütüphanenin misyon, vizyon ve amacı & $\nabla$ & $\nabla$ & $\otimes$ & $\diamond$ \\
\hline Kütüphane yönergesi ve personel görev tanımları & $\nabla$ & $\nabla$ & $\otimes$ & $\diamond$ \\
\hline Üniversitenin tanıımı ile ast-üst ilişkileri & $\nabla$ & $\nabla$ & $\otimes$ & $\diamond$ \\
\hline Kütüphane tanıtımı ile ast-üst ilişkileri & $\nabla$ & $\nabla$ & $\otimes$ & $\otimes$ \\
\hline Kullanıcı-personel ilişkileri ve davranış biçimleri & $\nabla$ & $\nabla$ & $\nabla$ & $\square$ \\
\hline Sorumlu olduğu uygulama ve hizmetler & $\nabla$ & $\nabla$ & $\nabla$ & $\nabla$ \\
\hline Otomasyon programı ve ilgili modül/modüller & $\nabla$ & $\nabla$ & $\otimes$ & $\diamond$ \\
\hline Klasik ve elektronik kataloglama ve sınıflama uygulaması & $\nabla$ & $\otimes$ & $\otimes$ & \\
\hline Üniversite ve kütüphane web sayfası üzerinden verilen hizmetler & $\nabla$ & $\nabla$ & $\otimes$ & $\diamond$ \\
\hline Kütüphane web sayfasının hazırlanması ve güncelliğinin sağlanması & $\nabla$ & $\otimes$ & $\otimes$ & \\
\hline Kütüphanecilik alanındaki sivil toplum kuruluşları & $\nabla$ & $\otimes$ & $\otimes$ & \\
\hline Önemli yayınevleri, veri tabanları ve içerikleri & $\nabla$ & $\nabla$ & $\otimes$ & \\
\hline Metadata ve veri tabanı mimarisi & $\nabla$ & $\otimes$ & $\otimes$ & \\
\hline Veri tabanlarındaki arama stratejileri & $\nabla$ & $\nabla$ & $\otimes$ & $\otimes$ \\
\hline APA, MLA, Harvard vb. standartlarında kaynakça hazırlatılması & $\nabla$ & $\otimes$ & $\otimes$ & \\
\hline Danışma hizmetleri & $\nabla$ & $\nabla$ & $\nabla$ & $\diamond$ \\
\hline Rezerve işlem ve hizmetleri & $\nabla$ & $\nabla$ & $\otimes$ & \\
\hline Basılı ve elektronik koleksiyon türleri ve içerikleri & $\nabla$ & $\nabla$ & $\otimes$ & $\otimes$ \\
\hline Raf okuma, bulma, yerleştirme, sayım gibi uygulamalar & $\nabla$ & $\nabla$ & 曰 & $\nabla$ \\
\hline Kütüphanecilik ile ilgili okumalar & $\nabla$ & $\nabla$ & $\otimes$ & \\
\hline Gerek duyulduğunda kısa süreli değerlendirme toplantıları & $\nabla$ & $\nabla$ & $\otimes$ & $\diamond$ \\
\hline Yarı zamanlı öğrenci programı çalışma koşulları & $\otimes$ & $\otimes$ & $\diamond$ & $\nabla$ \\
\hline Kütüphane katalogu web ara yüzünün kullanımı & $\nabla$ & $\nabla$ & $\nabla$ & $\otimes$ \\
\hline Seçim, sağlama ve ayıklama işlemleri & $\nabla$ & $\nabla$ & $\otimes$ & \\
\hline Kütüphaneler arası ödünç kitap ve makale fotokopisi hizmetleri & $\nabla$ & 四 & $\otimes$ & \\
\hline Teknik işlemlerin (barkod, etiket, güvenlik, vb.) uygulamalar & $\nabla$ & 曰 & $\nabla$ & \\
\hline Ofis programlarının kullanımı & $\nabla$ & $\nabla$ & $\otimes$ & $\otimes$ \\
\hline Tarayıcı, OCR ve metin düzeltme programları ve uygulamaları & $\nabla$ & $\nabla$ & $\nabla$ & $\nabla$ \\
\hline PDF, JPG gibi dosyalar ve çözünürlük ile ilgili konular & $\nabla$ & $\nabla$ & $\diamond$ & $\nabla$ \\
\hline Kongre, konferans, seminer ve eğitim toplantılarına katııım & $\nabla$ & $\nabla$ & $\otimes$ & \\
\hline Ödünç verme, iade, ayırtma ve gecikme bedeli işlemleri & $\nabla$ & $\nabla$ & $\otimes$ & \\
\hline Fotokopi, yazıcı gibi ofis araç gereçlerinin kullanımı & $\nabla$ & $\nabla$ & $\nabla$ & $\nabla$ \\
\hline Gelen-giden evrakın kaydedilmesi ve dosyalaması & $\nabla$ & $\nabla$ & $\otimes$ & \\
\hline Uzmanlık alanındaki uygulamalar ile ilgili anlatılar yaptırıması & $\nabla$ & $\otimes$ & $\diamond$ & \\
\hline Öğrendiklerini 20 dakikalık sunumla kütüphane personeliyle paylaşma & $\nabla$ & $\otimes$ & $\otimes$ & \\
\hline
\end{tabular}

paylaşımı ve daha verimli bir hizmet için programa gönüllü olarak katılmışlardır. Mentorluk programında, Tablo II'de belirtilen alanlarda uzmanlığı olanlarla, "gelişmiş", 
"orta" ve "bilgilendirme" düzeyinde tecrübe paylaşımına gidilmiş ve ortak bir dil oluşturulmuştur.

Üç aylık süre sonunda tam zamanlı yeni çalışanların işlerine hâkim olmaya başladıkları gözlemlenmiştir. Kütüphaneci çalışanımız için uygulamada, öncelik ve yoğunluk kataloglama ve sınıflama çalışmasına ayrılmıştır. Kütüphanenin personel durumu ve personelin birden çok konuda hizmet vermesi gerekliliği hususu da dikkate alınarak diğer alanlarda gelişmesi için gerekli destek ve yardımda bulunulmuştur. Memur çalışanımız için ise ödünç-iade ve danışma hizmeti öncelikli bir uygulama yapılmıştır.

2010 yılı Temmuz-Ağustos aylarında iki stajyer öğrenciye uygulan program katılımcılar tarafından olumlu bulunmuştur. Program çerçevesinde işlenen bir konunun üzerinde ne kadar durulacağına mentor ve danışan karar vermiştir. Staj süresinin kısıtlı olması nedeniyle öğrenildiği düşünülen konular üzerindeki uygulama erken sonlandırılmış, daha fazla uygulama gerektiren konuların süresi uzatılmıştır.

Yarı zamanlı̈öğrencilere uygulanan mentorluk programında, katılımcılar görevlerine hızla uygum sağlamış ve uygulama sırasında güçlükler çıkması halinde destek verilmeye devam edilmiştir.

Tam zamanlı kütüphaneci ve memura uygulanan program, uyum ve kendine güven açısından beklenenden daha fazla yarar sağlamıştır. Personelin işe uyum sağlamasının yanında, programın ilerleyen zamanlarında işlerini daha nasıl iyileştirebilecekleri yönünde eğilim gösterdikleri gözlenmiş ve aradıkları destek eksiksiz verilmiştir. Birinci ayın sonunda danışanlarda uyum sağlayamama yönünde endişe gözlense de ilerleyen toplantılarda ve yapılan değerlendirmelerde bu endişenin giderek azaldığı ve personelin kendine güveninin arttığı gözlenmiştir. İlk dönem sonunda programa katılan çalışanların kendilerine güvenen bir kişiliğe kavuştuğu gözlenmiştir. Programın ikinci döneminde ana görev alanları öncelikli tutularak uygulamalara devam edilmiştir.

Doğuş Üniversitesi Kütüphanesinde uygulanan mentorluk programı, mentor, yeni çalışanlar, kütüphane ve diğer kütüphanelere örnek olması bakımından çeşitli katkılar sağlamıştır. Uygulanan program ile;

1. Mentorun, yeni çalışanların ihtiyaçlarına uygun bir program geliştirmesine ve sunmasına,

2. Mentorun, iyi bir gözlem yapmasına ve kendi eksikliklerini fark etmesine,

3. Mentorun, tecrübelerinin yeni çalışanların performansına yansıtılmasına,

4. Mentorun, yeni çalışanlardaki değişim ve gelişimi gözlenmesine,

5. Yeni çalışana iş başında ve istenilen zamanda eğitimin sağlanmasına, 
6. Yeni çalışanlarda arzulanan davranışları geliştirmelerine ve farkındalık yaratılmasına,

7. Yeni çalışanların sürece aktif olarak ve daha erken sürede katılmasına,

8. Yeni çalışanların kurum kültürüne uyum sağlamalarına,

9. Yeni çalışanlara uygun bir eğitimin sunulmasına,

10. Yeni çalışanların işlerine yönelik olumlu tutumlar geliştirmesine,

11. Yeni çalışanların motivasyonunun artırılmasına,

12. Çalışanlar arasındaki iletişimin güçlenmesine,

13. Sorumluluk ve tecrübelerin çeşitli düzeylerdeki yeni çalışanlarla paylaşılmasına,

14. Takım çalışması, iletişim ve işbirliğine,

15. Kütüphane uygulama ve bilgi hizmetlerindeki verimliliğinin artmasına,

16. Mentorluk programının Türkiye'deki bir kütüphanede pilot olarak uygulanması suretiyle başka kütüphanelere örnek olmasına katkı sağlanmıştır.

\section{Sonuç}

Mentorluk, artan rekabetle değişen ürün/hizmet biçimleri ve kurumların çalışanlarına daha çok eğitim ve motivasyon sağlamak için çeşitli eğitim ve yönlendirme modellerine başvurmalarından dolayı çalışma yaşamında giderek önem kazanmaktadır. Günümüzde mentorluk kütüphanelerin başarısı için kritik bir uygulama haline gelmiştir; çünkü kurumlar bu programların gerçek yararlarının farkına varmışlardır. Kurumsal mentorluk programları birlikte öğrenme faaliyetleriyle gelişmiştir. Motivasyon, kariyer gelişimi, ekip oluşturma süreci gibi etkinlikler iyi personelin kurumlarında kalmalarını sağlamaktadır. Kişinin mentor olmasında güven oluşturma, kişisel farkındalık ve işbirliğine yatkınlığı gelişim rollerini önemli ölçüde etkilemektedir.

Mentorluk uygulamalarının günümüzde kütüphanelerde daha yaygın hale gelmesinin nedeni, genç çalışanların kariyer gelişimi arzusu ve yeni çalışanların hızla geliştirilerek verimliliğin artırılması isteğinden kaynaklanmaktadır. Dolayısıyla mentorluk uygulaması aracılığıyla çeşitli konularda uzman kütüphanecilerin tecrübelerinden yararlanılarak, yeni çalışanların yetiştirilmesi gerekli görülmektedir.

Türkiye'deki üniversite kütüphaneleri yetişmiş kütüphaneci açığını kapatmak, mevcut çalışanların hızla gelişimini sağlayarak bu sorunun giderilmesine katkı sağlamayı görev olarak algılamalıdır. Bu bakımdan üniversite kütüphaneleri mentorluk ilişkilerini, bilgi teknolojilerindeki gelişmeler ve kullanıc beklentilerindeki değişiklikleri dikkate alarak incelemeli, ihtiyaçlara göre kurumsal bir yapıya kavuşturmalı ve personelin 
eğitiminde uygulamalıdır. Öte yandan bu uygulamalar, personel eğitimi hususunda çözüm yolları arayan kütüphanelere katkı sağlamak bakımından yazılı hale getirilmeli ve yayımlanmalıdır.

Planlı ve çoğu bilinçli olmasa da Türkiye'deki kütüphanelerde uygulanan mentorluk etkinlikleri ve mentorluk konusunda kütüphaneciler bilinçlendirilmeli ve bu tür etkinliklerin kurumsal bir yapıya kavuşturulması için çalışmalar yapılmalıdır.

Mentorluk uygulamasının gelişmesi ve yaygınlaşması için kütüphane yöneticileri, yetişmiş personelin bu konuda kendilerini geliştirmeleri için teşvik etmeli, yeni kütüphanecilerin bu doğrultuda yetiştirilmesinin önünü açmalıdır.

Türkiye'de profesyonel kütüphaneciler sivil toplum kuruluşlarının çatısı altında ve gönüllü birlikteliklerle hem kendilerini geliştirmekte hem de kütüphanelere ve kütüphanecilik hizmetlerine önemli katkılar sağlamaktadır. Bu potansiyelin yeni kütüphanecilerin eğitiminde, mentorluk uygulamaları çerçevesinde kullanılması, yetişmiş kütüphaneci sorununun giderilmesine önemli katkılar sağlayacaktır.

Sivil toplum kuruluşları ve gönüllü işbirlikleri çerçevesinde bilgi paylaşımına gidilmeli ve bu konuda çalıştaylar yapılarak profesyonel kütüphanecilerin kendi aralarında uygulamalarda standardizasyon sağlamaları teşvik edilmelidir.

Akran destek mentorluğu çeşitli kademelerde yeni çalışanların yönlendirilmesi ve geliştirilmesinde etkili yollardan biridir. Bu nedenle kütüphanelerin akran destek mentorluğu yöntemlerinden etkili bir şekilde yararlanmaları önemli görülmektedir.

Şu halde Türkiye'de kütüphanecilik alanında söz sahibi olan kütüphanecilerin, mentorluk uygulamasının yeni kütüphanecilerin eğitimindeki olumlu katkılarını göz önüne almaları ve bu yönde gerekli çalışmaları yapmaları gerekli görülmektedir.

Mentorluk ilişkilerinin başarısı için kütüphane yöneticilerinin kütüphanede, adil, güven verici ve samimi bir ortam oluşturması mentorluk uygulamasının önemli bir koşuludur.

Doğuş Üniversitesi Kütüphanesinde stajyer, yarı zamanlı ve tam zamanlı personel için geliştirilen ve uygulanan mentorluk programı, personelin planlı eğitiminde olumlu geri bildirimler sağlamıştır. Hazırlanan plan çerçevesinde mentorluk programına alınan çalışanların hem kısa sürede gelişimi sağlanmış hem de kütüphane hizmetlerinin verimliliği artmıştır. Çalışanların daha etkili ve verimli bir şekilde geliştirilmesine aracılık eden bu uygulama için geliştirilen programın Türkiye'deki diğer meslektaşların önerileriyle elden geçirilmesi programın içeriğinin zenginleşmesi ve gelişmesine katkı sağlanmalıdır.

Literatür araştırması başlığı altında belirtilen çalışmaların ve Doğuş Üniversitesi Kütüphanesi'ndeki mentorluk uygulamalarının sonuçlarına göre, yeni kütüphanecilerin 
eğitilmesinde ve geliştirilmesinde mentorluk uygulamasının yararlı ve gerekli olduğu söylenebilir.

\section{Kaynakça}

Aydın, İ. (2008). Öğretimde denetim: Durum saptama değerlendirme ve geliştirme. Ankara, Pegem.

Bayır, D. (2007). Kütüphane ve bilgi merkezlerinde insan kaynakları yönetimi: performans değerlendirme sistemleri ve Koç Üniversitesi Kütüphanesi örneği. Yayımlanmamış doktora tezi. İstanbul Üniversitesi Sosyal Bilimler Enstitüsü Bilgi ve Belge Yönetimi Anabilim Dalı.

Bosch, E.K., Ramachandran, H., Lu'Evano, S., Wakiji, E. (2010). The resource team model: an innovative mentoring program for academic librarians. New Review of Academic Librarianship, $16,57-74$.

Culpepper, J.C. (2000). Mentoring academic librarians: the ultimate in career guidance. College \& Undergraduate Libraries, 7, 2, 71-81.

Çukadar, S., Gültekin, G., Çelik, S., Kahvecioğlu, K. (2011). Türkiye'de üniversite kütüphaneleri: Mevcut durum ve gelecek. Uluslararası Yüksek Öğretim Kongresi: Yeni Yönelişler ve Sorunlar, 27-29 Mayıs, İstanbul, Türkiye.

Holt, İ. ve Kızılaslan, D. (2004). Kütüphanecilikte sürekli eğitim uygulamaları ve Koç Üniversitesi Suna Kıraç Kütüphanesi örneği. Kütüphaneciliğin Destanı Uluslararası Sempozyumu, Ankara (Turkey),21-24 October 2004 içinde. (Editörler F. ÖZDEMIRCi, S. ARSLANTEKIN) Ankara: Ankara Üniversitesi Dil ve Tarih-Coğrafya Fakültesi. 25 Mayıs 2010 tarihinde http://eprints.rclis.org/ bitstream/10760/5874/1/SurekliEgitim.pdf adresinden erişildi.

Kram, K.E. (1983). Phases of the mentor relationship. Academy of Management Journal, December, 26. 4. 608-625.

Kuyper-Rushing, L. (2001). A formal mentoring program in a university library: components of successful experiment. The Journal of Academic Librarianship, 27, 6, 440-446.

Lee, M. (2009). Growing librarians: mentorship in an academic library. Library Leadership \& Management, 23, 1. Winter, 31-37.

Navitas Eğitim, Danışmanlık ve koçluk hizmetleri. (2010). Yönetimde Koçluk ve Mentorluk. AYMED Toplantısı 28 Nisan 2010, Marmara Yelken Kulübü Erenköy / Kadıköy-İstanbul. 25 Mayıs 2010 tarihinde http://www.navitas-tr.com adresinden erişidi.

Özkalp, E., Kırel, Ç, Sungur, Z, Cengiz, A.A. (2006). Örgütsel toplumsallaşma sürecinde mentorluk ve mentorun yeri ve önemi: Anadolu Üniversitesi araştırma görevlileri üzerine bir inceleme. Anadolu Üniversitesi Sosyal Bilimler Dergisi, 6 (2) 55-69.

Ptolomey, J. (2008). Mentoring: supporting the library and information professional? Health Information \& Libraries Journal, December, 25, 4, 309-312.

Stueart, R.D., Sullivan, M. (2010). Developing library leaders : A how to do it manual for coaching, team building, and mentoring library staff. New York: Neal - Schuman Publishers Inc.

Uçkun, G. ve Kılınç, İ. (2007). Koçluk ve mentorluk. Ankara, Ürün Yayınları. 
The University of Delaware (2009). The University of Delaware Library Assembly of Professional Staff: Mentoring Program Guidelines and Procedures. 18 Mayıs 2011 tarihinde http://www.lib. udel.edu/udlaps/ activities/mentoring.htm adresinden erişildi.

Wojewodzki, C., Stein, L. \& Richardson, T., (1998). Formalizing an informal process: developing a mentoring program in a university library. Technical Services Guarterly, 15 (3), 1-19.

Yılmaz, B. (2008). Türkiye'de halk kütüphaneleri bölge seminerleri: "ilyi uygulama örneği” olarak bir deneyimin değerlendirilmesi. Türk Kütüphaneciliği, 22 (1) 107-128.

\section{Ek-1}

Mentor Adayları İçin Öz Değerlendirme (Stueart ve Sullivan, 2010, 77-78)

Kurumsal bir mentorluk görevini üstlenmeden önce aşağıdaki soruları inceleyiniz ve olumlu bulduklarınıza "evet" yazınız:

1. İyi bir mentor olmak için yeterli tecrübeye sahip miyim? Değilse öğrenecek kapasite ve yeteneğe sahip miyim?

2. Sahip olduğum kariyer, itibar, yetenek uzmanlık ve mesleki tecrübe bir mentorluk rolünü üstlenmek için yeterli mi?

3. İyi bir mentorluk ilişkisi geliş̧tirmek için mesleki çevre, danışmanlık ve liderlik becerilerim var mı?

4. Potansiyel adaylar için yönetsel ve hızla değişen teknoloji de dahil olmak üzere güncel gelişmeler konusunda yeterli bilgiye sahip miyim?

5. Başarılı bir mentor olmak için mevut iş yükü altında mentorluk sorumluğu üstlenmek üzere yeterli zaman, sabır ve enerjiye sahip miyim?

6. Nasıl ya da ne tür bir mentorluk ilişkisi ortaya koymak istiyorum? Böylesine profesyonel bir etkileşim içine girmem kişisel ve profesyonel yarar sağlar mı?

7. Kişisel ve kurumsal yeteneklerin gereklilik ve bilgi süreçlerini kendi kendime değerlendirebilir miyim? Çalıştığım kurumun gelişimi için tecrübesiz personeli yönlendirme konusunda yetenekli miyim?

8. Tecrübesiz personeli gözlemlemede, gelişim sonuçlarını değerlendirmede, uygulamada ve potansiyel çözümlere yapacağım yorumlarda yargılayıcı olmayan bir tutum izleyebilir miyim?

9. Doğru girdi, geri bildirim ve talimatları adil ve uygun bir şeklide sunabilir miyim? Kişilerarası iletişim kurma becerileri, kişisel hedefler ve değerleri belirleme, bunları 
açıkça tartışma ve bu suretle arzu edilen geri beslemeyi sağlayacak yeteneğim var mı ya da geliştirebilir miyim?

10. Insanlarla iletişim kurmakta başarılı mıyım ve iyi bir dinleyici miyim? Sorumlu olduğum tecrübesiz personeli keşfetmek, sorunlarına çözüm önermek için gerekli berilere sahip miyim?

11. Çeşitli aşamalarda arzu edilen bağımlılık veya bağımsızlık derecesinin farkına varmak için yeterince zeki miyim? Danışmanlık ve dikte etme arasındaki ince çizgiyi fark edebilir miyim?

12. Kendi fikirlerimi empoze etmeden, değerleri ve görüşleri tanıtmak için yeterince adil davranabilir miyim?

13. Profesyonel danışmanlık ve kişisel problem çözme arasındaki ince çizgiyi tanıma yeteneğine sahip miyim? Hangi iş ilişkisi ya da ilişkilerinden kaçınmalıyım? 